УДК $37.02+001.891$

DOI:

Марина Загорулько, асистент кафедри романо-германських мов і перекладу Національного університету біоресурсів і природокористування Украӥни

\title{
МЕТОДОЛОГІЯ ВИЗНАЧЕННЯ СУКУПНОСТІ ДИДАКТИЧНИХ УМОВ ФОРМУВАННЯ ДОСЛІДНИЦЬКО-ДІАГНОСТИЧНИХ УМІНЬ У МАЙБУТНІХ ВЧИТЕЛІВ ПОЧАТКОВОЇ ШКОЛИ
}

У статті висвітлюються питання методології визначення сукупності дидактичних умов (провідної та супідрядних), формування дослідницько-діагностичних умінь у майбутніх вчителів початкової школи у прочесі вивчення психолого-педагогічних дисциплін, проаналізовано методологічні підходи реалізація та урахування положень яких уможливлює дефініџіацію досліджуваних дидактичних умов: провідна дидактична умова та супідрядні дидактичні умови.

Ключові слова: методологія; дидактичні умови; дослідницько-діагностичні уміння; майбутні вчителі початкової школи.

Jim. 12.

Maryna Zahorulko, Assistant Lecturer of Romance and Germanic Languages and Translation Department National University of Life and Environmental Sciences of Ukraine

\section{METHODOLOGY OF DETERMINING OF THE DIDACTICAL CONDITIONS OF FORMATION RESEARCH-DIAGNOSTIC SKILLS OF FUTURE TEACHERS OF ELEMENTARY SCHOOL}

Modern students of institutions of higher education are in the conditions of globalization of information flows, widely apply modern information technology, often combining training activities with work, to obtain higher education are pragmatically focused on the use of individual learning methods, freedom from collective and institutional influences. While studying on the first year students have a solid idea of the peculiarities of future professional activity, therefore, the need to acquire their professional competencies as components of professional competence is quite evident. That is why the question of determining some methodological foundations for defining the didactic conditions in studies on the theory of teaching as a whole and the theory of teaching in higher education in particular is still relevant.

The purpose of this article is to carry out a thorough analysis of methodological approaches to determining the leading and subordinate didactic conditions for the development of research and diagnostic skills for future primary school teachers.

The article deals with the questions of the methodology for determining of didactic conditions (leading and subordinate), the formation of research and diagnostic skills for future teachers of elementary school in the process of studying psychological and pedagogical disciplines, analysing methodological approaches, implementation of which allows for the definition of the studied didactic conditions in the wording: the leading didactic condition (integration of self-education and academic activity of future teachers of elementary school in the process of teaching psychological and pedagogical disciplines on the basis of increasing the research component), undergraduate didactic conditions (individualization of the process of teaching psychological and pedagogical disciplines as a means of providing the necessary and motivational basis for the formation of research and diagnostic skills of future teachers of elementary school; creation of IT didactic environment for the formation of research competence of future primary school teachers; strategization of the process of teaching psychological and pedagogical disciplines; activation of research and reflection activity of students - future teachers of elementary school).

Keywords: methodology; didactic conditions; research and diagnostic skills; future teachers of elementary school.

П остановка проблеми. Актуальна потреба оновлення процесу фахової підготовки студентів у вищій школі в цілому, а також студентів - майбутніх учителів, у системі вищої педагогічної школи зумовлює зміну знаннєво-орієнтованої парадигми освіти на компетентнісно-орієнтовану. Задля того, щоб учителі початкової школи могли здійснювати та переформатовувати власну професійну діяльність на компетентнісній основі, вона має реалізуватися вже під час підготовки майбутніх фахівців у період навчання у вищій педагогічній школі.

Аналіз психолого-педагогічної літератури та дисертаційних праць засвідчує наявність посиленої уваги науковців до вивчення проблеми формування дослідницько-діагностичних умінь, які є основою забезпечення творчого зростання молодих фахівців освітньої галузі в умовах 
МЕТОДОЛОГІЯ ВИЗНАЧЕННЯ СУКУПНОСТІ ДИДАКТИЧНИХУМОВ ФОРМУВАННЯ ДОСЛІДНИЦЬКО-ДІАГНОСТИЧНИХ УМІНЬ У МАЙБУТНІХ ВЧИТЕЛІВ ПОЧАТКОВОӤ ШКОЛИ

інноваційної педагогічної діяльності, підвищення їхьої активності та потенціалу щодо вияву креативності у власній професійно-педагогічній підготовці. Зростає увага освітян вищої школи до створення необхідних умов у педагогічних закладах вищої освіти для формування дослідницько-діагностичних умінь саме в майбутніх учителів початкової школи, як складової вдосконалення їхньої педагогічної майстерності.

Аналіз останніх досліджень і публікацій. Проблемою визначення педагогічних умов у різних напрямах дослідження в межах педагогічної науки займалися вчені-дослідники: В. Андрєєв, I. Аксаріна, О. Бєлкін, Є. Ганін, О. Городиська, Н. Іпполітова, Н. Кузьміна, О. Малихін, В. Нестеров, Н. Стеріхова та інші. Науковці тлумачать поняття "педагогічна умова" як точно визначену умову, яка безпосередньо впливає (стимулює або стримує) на виникнення та розвиток педагогічних явищ, процесів, систем, якостей особистості. А. Алексюк, А. Аюрзанайн, П. Підкасистий під терміном "педагогічні умови" розглядають чинники, котрі діють певним чином на процес досягнення мети. Дидактичні умови як різновид педагогічних умов у своїх працях розглядаютьА. Андреєв, О. Бондаревська, С. Гончарова, М. Крива, О. Малихін, М. Малоіван, О. Сапрунова та інші.

Мета цієї роботи полягає в тому, щоб здійснити грунтовний аналіз методологічних підходів до визначення провідної та супідрядних дидактичних умов формування дослідницькодіагностичних умінь у майбутніх учителів початкової школи.

Виклад основного матеріалу. У наукових джерелах знаходимо різноманітні визначення поняття “умова", які в той же час мають певні подібності. Наприклад, з позицій філософії іiі потрактовують як філософську категорію, у якій відображені загальні взаємовідношення речі та тих чинників, завдяки яким вона виникла та функціонує. Властивості речей перетворюються 3 можливих у дійсні завдяки існуванню певних умов [3, 178].

Проведений аналіз філософської, психологопедагогічної, методичної та соціологічної літератури дає змогу стверджувати, що категорія “умова” розглядається як складова будь-якого процесу, зокрема й процесу підготовки майбутніх фахівців до професійної діяльності.

Філософський контекст: термін "умова", як уже було зазначено, трактується як категорія, у якій відображені загальні відношення речей до тих чинників, завдяки яким вона з'являється й функціонує.
Завдяки умовам складаються середовища, у яких виникають, існують й розвиваються ті чи інші явища та процеси. За межами цього середовища вони не зможуть існувати.

У психології здебільшого під терміном “умова” розглядають єдність явищ зовнішнього та внутрішнього середовища, котрі можуть впливати на розвиток певного психічного явища.

Саме тому із психологічної точки зору розуміємо, що умова - то є певне різноманіття зовнішніх впливів об'єктивного світу на предмет.

У педагогічній практиці розмежовують достатні й необхідні умови. Достатні умови безпосередньо викликають дію предмета, а необхідні умови вже наявні тоді, коли відбулася якась певна дія.

Застосовуючи термін “педагогічна”, як правило, мають на увазі процес підготовки фахівця чи спеціаліста конкретної галузі, який буде підготовлений за створення визначеного комплексу умов.

У педагогічній науці існують різні підходи до трактування суті поняття “педагогічні умови”. Педагогічні умови - це педагогічні обставини, які відповідають певним чинникам, котрі сприяють або протидіють вияву педагогічних закономірностей, викликаних дією цих чинників [3, 80].

I. Аксаріна до педагогічних умов відносить ті, які створюють 3 певним наміром в освітньому процесі й вони забезпечують найефективніше протікання цього процесу $[1,12]$.

Є. Ганін у дослідженні педагогічних умов застосування інформаційно-комунікаційних технологій у самоосвіті фахівців під поняттям “педагогічні умови” розглядає неподільну єдність взаємопов’язаних умов, які є необхідними для забезпечення цілеспрямованого виховного й освітнього процесу, а також за активного використання сучасних інформаційних технологій, які використовуються для забезпечення формування особистості, наділеної певними якостями [6].

Діяльність майбутнього фахівця передбачає створення особливих умов формування й розвитку готовності до здійснення його функціональних обов'язків і має свої характерні особливості. Від сукупності відповідних його професійній діяльності принципів, функціональної спрямованості навчання, застосування методів і прийомів, засобів і педагогічних умов, за допомогою яких буде здійснюватися процес навчання, залежить успіх й ефективність професійної підготовки майбутнього педагога.

На сучасному етапі переформатування сучасних закладів вищої освіти в дослідженнях 


\section{МЕТОДОЛОГІЯ ВИЗНАЧЕННЯ СУКУПНОСТІ ДИДАКТИЧНИХУМОВ ФОРМУВАННЯ ДОСЛІДНИЦЬКО-ДІАГНОСТИЧНИХ УМІНЬ У МАЙБУТНІХ ВЧИТЕЛІВ ПОЧАТКОВОӤ ШКОЛИ}

психолого-педагогічного спрямування, які розглядають проблеми вдосконалення ефективної діяльності педагогічних систем та покращення дієвості освітнього процесу, постає одне питання, яке викликає найбільший інтерес - це виділення, обгрунтування та перевірка дієвості педагогічних умов, що якнайкраще забезпечує успішність підготовки майбутніх фахівців до їхньої професійної діяльності у подальшому.

О. Бражнич та Н. Іполлітова тлумачать поняття “педагогічна умова" як точно визначену умову, яка безпосередньо впливає (стимулює або стримує) на виникнення та розвиток педагогічних явищ, процесів, систем, якостей особистості [5; 8].

У дослідженнях А. Алексюка, А. Аюрзанайна, П. Підкасистого під терміном "педагогічні умови” розглядаються чинники, які діють певним чином на процес досягнення мети, одночасно їх розділяють на:

а) зовнішні: дружелюбні відносини викладачів і студентів; об'єктивну оцінку досягнень у навчальному процесі; місцезнаходження закладу освіти, матеріально-технічне забезпечення навчальних приміщень, погодні умови, клімат тощо;

б) внутрішні (індивідуальні): особисті якості, властиві студентам (стан здоров'я, риси характеру, темперамент, наявний рівень знань, умінь, навичок, досвіду, мотивація до здійснення професійної діяльності тощо) [2].

У дослідженні О. Бражнич педагогічні умови визначаються як сукупність реально існуючих можливостей змісту, організаційних методів і форм, матеріально-технічного забезпечення та можливостей реалізації у практиці педагогічного процесу, який гарантує ефективне досягнення бажаної цілі.

Педагогічні умови В. Андрєєв розглядає як результат планомірного відбору, конструювання та застосування елементів змісту, методів і прийомів, а також організаційних форм навчання для досягнення поставлених цілей.

Підсумовуючи все сказане вище, можемо констатувати, що науковці педагогічні умови тлумачать як цілісність об'єктивних можливостей, котрі гарантують можливість успішного вирішення поставлених завдань [2] або як певну функціональну залежність значущих складників педагогічного явища від єдності об'єктів (речей, їхніх станів, процесів, взаємодій) у різноманітних виявах.

Характерною рисою всіх можливих потрактувань цього поняття є спрямованість створюваних умов на покращення взаємодії учасників педагогічного процесу під час вирішення поставлених перед ними дидактичних завдань. Таким чином, можна дійти висновку, що педагогічні умови розглядаємо як цілісність певних чинників, котрі надають можливість організовувати й регулювати взаємодію об'єктів і явищ педагогічного процесу для досягнення поставленої мети.

У педагогічній науці умови розглядають як обставини чи особливості реальної дійсності, за яких щось здійснюється або відбувається.

3 цього випливає, що дидактичні умови - то $є$ сукупність обставин, які гарантують ефективність протіканню навчального (освітнього) процесу.

У психолого-педагогічних джерелах можна знайти багато трактувань поняття “дидактична умова”. Науковці акцентують увагу на тому, що дидактичною умовою можна вважати цілісну єдність об'єктивних можливостей змісту навчання, методів, його організаційних форм i матеріально-технічних можливостей здійснення процесу навчання, яка забезпечує максимально ефективне розв'язання висунутого завдання. А. Андреєв визначає дидактичну умову як обставину процесу навчання, яка є підсумком цілеспрямованого відбору, моделювання й використання складових змісту, методів і прийомів, а також організаційних форм навчання для досягнення поставленої перед науковцями дидактичної мети. Ми в цілому погоджуємося 3 цим визначенням.

О. Малихін під дидактичними умовами розглядає визначену комплексну цілісність потенційно ємких дидактичних ресурсів, створення й практична реалізація їх вихідних положень буде сприяти максимальній ефективності провадження процесу навчання, ураховуючи постійно змінювані вимоги до якості отриманих знань, умінь, навичок, досвіду практичної діяльності суб'єктів навчання, що забезпечують формування необхідних компетенцій і компетентностей у своїй структурно-функціональній єдності [10].

На основі проведеного аналізу низки дисертаційних праць 3 теорії навчання у закладах вищої освіти, здійснених українськими науковцями, пропонуємо декілька, на наш погляд, найбільш влучних прикладів того, як визначається сукупність дидактичних умов дослідниками відповідно до обраної ними теми роботи.

О. Сапрунова: тема дослідження “Дидактичні умови розвитку інтелектуальної обдарованості учнів початкової школи" розробила та теоретично обгрунтувала сукупність дидактичних умов розвитку інтелектуальної обдарованості учнів початкової школи: актуалізація мотиваційноціннісної основи інтелектуальної діяльності учнів 


\section{МЕТОДОЛОГІЯ ВИЗНАЧЕННЯ СУКУПНОСТІ ДИДАКТИЧНИХУМОВ ФОРМУВАННЯ ДОСЛДНИЦЬКО-ДІАГНОСТИЧНИХ УМІНЬ У МАЙБУТНІХ ВЧИТЕЛІВ ПОЧАТКОВОӤ ШКОЛИ}

початкової школи; створення стимулювальнопроблемного середовища на засадах інтеграції інноваційних технологій навчання в початковій школі та IT-технологій; індивідуалізація навчання інтелектуально обдарованих дітей з урахуванням особливостей зміступочаткової освіти; цілеспрямоване формування рефлексійних умінь як засобу реалізації процесів само (самоактуалізація, самонавчання, самооцінка, самовдосконалення, самореалізація) [12].

Є. Гончарова у своїй дисертаційній праці на тему: “Диференціація навчальних фахових дисциплін майбутніх учителів іноземної мови у вищих педагогічних закладах" виявила сукупність дидактичних умов диференціації навчання фахових дисциплін майбутніх учителів іноземної мови у вищих педагогічних навчальних закладах: формування мотиваційно-стимулювальної основи для засвоєння потенційно максимально можливого обсягу професійно значущого матеріалу; проектування і реалізація дидактичної взаємодії в системі “викладач-студент” з урахуванням індивідуально-психологічних особливостей суб'єктів навчального процесу, організованого на диференційній основі; імплементація ієрархічно впорядкованої блоково-структурної організації змісту навчання фахових дисциплін на диференційній основі; інтенсифікація рефлексивноаналітичної діяльності студентів 3 урахуванням специфіки підготовки з іноземних мов [7].

О. Бондаревська у роботі “Формування індивідуальних стратегій самостійно-пізнавальної діяльності студентів у процесі вивчення гуманітарних дисциплін” визначила сукупність дидактичних умов, створення яких забезпечує ефективність розгортання дидактичної моделі в освітньому процесі вищої школи: оптимізація самостійно-пізнавальної діяльності в логіці професійної самоактуалізації студентів; створення інтегративного освітнього простору на основі використання дидактичного потенціалу гуманітарних дисциплін; застосування інформаційнокомунікаційних технологій навчання як засобу інтенсифікації самостійно-пізнавальної діяльності студентів; забезпечення дидактичної адаптивності форм, методів, прийомів і засобів самостійнопізнавальної діяльності задля індивідуалізації й диференціації цієї діяльності [4].

М. Малоіван: тема дослідження “Дидактичні умови індивідуалізації самостійної навчальної діяльності студентів філологічних спеціальностей засобами інформаційних технологій” виділила дидактичні умови, за яких відбувається індивідуалізація самостійної навчальної діяльності студентів філологічних спеціальностей: активація у навчальному процесі сучасного арсеналу інформаційних технологій; розробка індивідуальних освітніх маршрутів на основі застосування сучасних інформаційних технологій; забезпечення варіативності завдань самостійної навчальної діяльності та активацію у студента на цій основі рефлексивних механізмів; асинхронізація самостійної навчальної діяльності студентів філологічних спеціальностей засобами інформаційних технологій [11].

У дисертації М. Кривої на тему “Формування творчої особистості учня в процесі дослідницької діяльності (на матеріалі природничих матеріалів)" розроблено дидактичні умови формування творчої особистості учня в процесі дослідницькоӥ діяльності: конструювання змісту дослідницької діяльності учнів із врахуванням сучасних екологічних та валеологічних проблем сталого розвитку суспільства; створення творчого особистісно зорієнтованого навчального середовища; управління дослідницькою діяльністю учнів на засадах паритетної взаємодії суб'єктів навчально-виховного процесу [9].

Висновки. Таким чином, на основі узагальнення теоретичного матеріалу та практичного досвіду здійснення педагогічних досліджень 3 теорії навчання ми виділяємо сукупність дидактичних умов формування дослідницько-діагностичних умінь у майбутніх учителів початкової школи і представляємо їх на двох рівнях. Провідна дидактична умова інтеграція самоосвітньої й академічної діяльності майбутніх учителів початкової школи у процесі навчання психолого-педагогічних дисциплін на засадах збільшення науково-дослідницькой складової.

Супідрядні дидактичні умови:

- індивідуалізація процесу навчання психологопедагогічних дисциплін як засіб забезпечення потребнісно-мотиваційної основи формування дослідницько-діагностичних умінь майбутніх учителів початкової школи;

- створення IT-дидактичного середовища формування дослідницької компетентності майбутніх учителів початкової школи;

- стратегізація процесу навчання психологопедагогічних дисциплін;

- активація дослідицько-рефлексійної діяльності студентів - майбутніх учителів початкової школи.

Перспективним для нашого дослідження вважаємо конкретизацію кожної з дидактичних умов формування дослідницько-діагностичних умінь у майбутніх вчителів початкової школи у процесі вивчення психолого-педагогічних дисциплін. 


\section{МЕТОДОЛОГІЯ ВИЗНАЧЕННЯ СУКУПНОСТІ ДИДАКТИЧНИХУМОВ ФОРМУВАННЯ ДОСЛДНИЦЬКО-ДІАГНОСТИЧНИХ УМІНЬ У МАЙБУТНІХ ВЧИТЕЛІВ ПОЧАТКОВОЇ ШКОЛИ}

\section{ЛІТЕРАТУРА}

1. Аксарина И. Ю. Педагогические условия адаптации выпускников школ на этапе перехода от общего к высшему профессиональному образованию: автореф. дис. на соискание научн. степени канд. пед. наук:. 13.00.01. Курганский гос. ун-т. Москва, 2006. 19 с.

2. Алексюк А. М., Аюрзанайн А. А., Підкасистий П. І. Організація самостійної роботи студентів в умовах інтенсифікації навчання : навчальний посібник. Київ, 1993.336 с.

3. Андреев А. А. Дидактические основы дистанционного обучения в высших учебных заведениях : дис. ... д.пед.н. : 13.00.02. Москва, 1999. 289 с.

4. Бондаревська О. М. Формування індивідуальних стратегій самостійно-пізнавальної діяльності студентів у процесі вивчення гуманітарних дисциплін: автореф. дис. на здобуття наук. ступеня канд. пед. наук : 13.00.09. Тернопіль, 2018.21 с.

5. Бражнич О. Г. Педагогічні умови диференційованого навчання учнів загальноосвітньої школи : дис. ... канд. пед. наук: 13.00.07. Кривий Ріг, 2001. 238 с.

6. Ганин Е. А. Педагогические условия использования современных информационных и коммуникационных технологий для самообразования будущих учителей URL: http://ito. edu. ru/2003/VII/VII0-1673.html.

7. Гончарова Є. Є. Диференціація навчальних фахових дисциплін майбутніх учителів іноземної мови у вищих педагогічних закладах : автореф. дис. на здобуття наук. ступеня канд. пед. наук : 13.00.09. Тернопіль, 2015. 21 с.

8. Ипполитова Н. В. Система профессиональной подготовки студентов педагогического вуза: личностный аспект: монография. Шадринск, 2006. 236 с.

9. Крива М. В. Формування творчої особистості учня в процесі дослідницької діяльності (на матеріалі природничих матеріалів): автореф. дис. на здобуття наук. ступеня канд. пед. наук : 13.00.09. Тернопіль, 2014. $19 \mathrm{c}$.

10. Малихін О. В. Методологічні основи визначення дидактичних умов у дослідженнях з теорії навчання (у вищій школі) Наукові праці Чорноморського державного університету імені Петра Могили комплексу “Києво-Могилянська академія”. Сер. : Педагогіка. 2013. Т. 215, Вип. 203. С. 11-14.

11. Малоіван М. В. Дидактичні умови індивідуалізації самостійної навчальної діяльності студентів філологічних спеціальностей засобами інформаційних технологій: автореф. дис. на здобуття наук. ступеня канд. пед. наук : 13.00.09. Тернопіль, 2016. 21 с.

12. Сапрунова О. Г. Дидактичні умови розвитку інтелектуальної обдарованості учнів початкової школи : автореф. дис. на здобуття наук. ступеня канд. пед. наук : 13.00.09. Тернопіль, 2019. 21 с.

\section{REFERENCES}

1. Aksarina, I. Yu. (2006). Pedagogicheskiye usloviya adaptatsii vypusknikov shkol na etape perekhoda ot obshchego $\mathrm{k}$ vysshemu professionalnomu obrazovaniyu [Pedagogical conditions of adaptation of school graduates at the stage of transition from general to higher professional education]. Extended abstract of candidate's thesis. Kurganskiy State university. Moscov, 19 p. [in Russian].

2. Aleksiuk, A. M., Aiurzanain, A. A. \& Pidkasystyi, P. I. (1993). Orhanizatsiia samostiinoi roboty studentiv $v$ umovakh intensyfikatsii navchannia [Organization of independent students work in intensification training conditions]. Kyiv, 336 p. [in Ukrainian].

3. Andreyev, A. A. (1999). Didakticheskiye osnovy distantsionnogo obucheniya $\mathrm{v}$ vysshikh uchebnykh zavedeniyakh [Didactic basics of distance learning in higher education institutions]. Doctor's thesis. Moscov, 289 p. [in Russian].

4. Bondarevska, O. M. (2018). Formuvannia indyvidualnykh stratehii samostiino-piznavalnoi diialnosti studentiv u protsesi vyvchennia humanitarnykh dystsyplin [Formation of individual strategies of selfcognitive activity of students in the process of studying humanitarian disciplines]. Extended abstract of candidate's thesis. Ternopil, 21 p. [in Ukrainian].

5. Brazhnych, O. H. (2001). Pedahohichni umovy dyferentsiiovanoho navchannia uchniv zahalnoosvitnoi shkoly [Pedagogical conditions of differentiated teaching of pupils of a secondary school]. Candidate's thesis. Kryvyi Rih, 238 p. [in Ukrainian].

6. Ganin, E. A. Pedagogicheskiye usloviya ispolzovaniya sovremennykh informatsionnykh i kommunikatsionnykh tekhnologiy dlya samoobrazovaniya budushchikh uchiteley [Pedagogical conditions for the use of modern information and communication technologies for self-education of future teachers]. Available at: http://ito. edu. ru/2003/VII/VII-0-1673.html. [in Russian].

7. Honcharova, Ye. Ye. (2015). Dyferentsiatsiia navchalnykh fakhovykh dystsyplin maibutnikh uchyteliv inozemnoi movy u vyshchykh pedahohichnykh zakladakh [Differentiation of the professional specialization disciplines of future foreign language teachers in higher educational institutions]. Extended abstract of candidate's thesis. Ternopil, 21 p. [in Ukrainian].

8. Ippolitova, N. V. (2006). Sistema professionalnoy podgotovki studentov pedagogicheskogo vuza: lichnostnyy aspekt [The system of professional training of pedagogical university students: the personal aspect]. Shadrinsk, 236 p. [in Russian].

9. Kryva, M. V. (2014). Formuvannia tvorchoi osobystosti uchnia v protsesi doslidnytskoi diialnosti (na materiali pryrodnychykh materialiv) [Formation of the student's creative personality in the process of research activity (on the material of natural materials)]. Extended abstract of candidate's thesis. Ternopil, 19 p. [in Ukrainian].

10. Malykhin, O. V. (2013). Metodolohichni osnovy vyznachennia dydaktychnykh umov u doslidzhenniakh z teorii navchannia (u vyshchii shkoli) [Methodological foundations for the definition of didactic conditions in studies on the theory of teaching (in higher education)]. Scientific works of the Petro Mohyla Black Sea State University of the Kyiv-Mohyla Academy complex. Series: Pedagogy. pp. 11-14. [in Ukrainian].

11. Maloivan, M. V. (2016). Dydaktychni umovy indyvidualizatsii samostiinoi navchalnoi diialnosti 


\section{ВИВЧЕННЯ ІНОЗЕМНОЇ МОВИЗА ДОПОМОГОЮСИНХРОННОГО 3D ВІРТУАЛЬНОГО СЕРЕДОВИЩА}

studentiv filolohichnykh spetsialnostei zasobamy informatsiinykh tekhnolohii [Didactic conditions of individualization of independent educational activity of students of philological specialties by means of information technologies]. Extended abstract of candidate's thesis. Ternopil. 21 p. [in Ukrainian].
12. Saprunova, O. H. (2019). Dydaktychni umovy rozvytku intelektualnoi obdarovanosti uchniv pochatkovoi shkoly [Didactic conditions for the development of intellectual giftedness of elementary school students]. Extended abstract of candidate's thesis. Ternopil, 21 p. [in Ukrainian].

Стаття надійшла до редакції 24.07.2019

УДК 37.091:378

DOI:

Наталія Буряченко, викладач методист вищої категорії Украӥнського політехнічного технікуму

\section{ВИВЧЕННЯ ІНОЗЕМНОЇ МОВИ ЗА ДОПОМОГОЮ СИНХРОННОГО ЗD ВІРТУАЛЬНОГО СЕРЕДОВИЩА}

У статті представлено актуальність необхідності пошуку нових методів і технологій викладацькоі діяльності шодо вивчення іноземної мови, які є адекватними сучасним тендениіям і вимогам суспільства. Узагальнено аналіз перспективи застосування синхронного $3 D$ віртуального середовища для можливості здійснення дистанційного навчання іноземної мови, як однієї з умов якісної підготовки майбутніх фахівців до професійної діяльності. Охарактеризовано низку загальних особливостей, переваг упровадження віртуального навчального середовища в умовах досліджуваної технологї, щуо враховує психолого-педагогічні особливості студентів, які спрямовані на успішний розвиток продуктивного мислення та навчальної діяльності.

Ключові слова: асинхронні засоби навчання; синхронні засоби навчання; електронне віртуальне середовище; дистаниійна освіта; Інтернет-технологї.

Jim. 12.

Nataliya Buryachenko, Lecturer-Methodist of the highest category of the Ukrainian Polytechnic College

\section{FOREIGN LANGUAGE LEARNING VIA SYNCHRONOUS 3D VIRTUAL ENVIRONMENT}

Learning a foreign language is considered in Ukraine as a necessary condition for admission to higher education institutions for highly paid professions and as an important part of globalization and international communication. The emphasis on learning a foreign language led to the introduction of a wide range of measures for effective language acquisition, from traditional English courses taught in the classroom of the University, to the use of synchronous-asynchronous learning tools.

Learning through the Internet as a kind of distance learning "has the ability to be an ideal means of learning a foreign language, as synchronous and asynchronous technologies provide a large number of functions to ensure the organization and conduct of creative teaching activities, but the analysis of recent studies and publications showed that in the psychological and pedagogical, scientific and special literature is not sufficiently investigated the implementation of virtual electronic learning environments.

The article presents the relevance of the need to find new methods and technologies of teaching activities for the study of a foreign language, which are adequate to modern trends and requirements of society. The analysis of the prospects of application of synchronous $3 D$ virtual environment for the possibility of distance learning of a foreign language as one of the conditions of quality training of future specialists for professional activity is generalized. A number of General features, advantages, introduction of the virtual educational environment, in the conditions of the investigated technology considering psychological and pedagogical features of students, which are directed on development of productive thinking and educational activity, are characterized.

Language learning in a $3 D$ synchronous virtual environment is still at an experimental stage, with great potential for full immersion in distance learning programs. No change in the 21 st century will be as significant or as far-reaching as distance learning, and if this is the case, the virtual learning environment in one form or another will play a very important role in educational programs.

Keywords: asynchronous learning tools; synchronous learning tools; electronic virtual environment; distance education; Internet technologies.

$\Pi$

остановка проблеми. Вивчення іноземної мови розглядається в Україні як необхідна умова для вступу до закладів вищої освіти на високооплачувані професії і як важлива частина глобалізації і міжнародного спілкування. 